\title{
Interaction of Pathogens Associated with Rhizome Rot Complex Disease in Ginger
}

\author{
H. S. Mahesha ${ }^{1^{*}}$, M. R. Ravikumar ${ }^{2}$, V. Suryanarayana ${ }^{3}$, \\ S. T. Prabhu ${ }^{2}$ and B. R. Jagadeesh ${ }^{2}$ \\ ${ }^{1}$ Department of Plant Pathology, UAS, Dharwad, Karnataka, India \\ ${ }^{2}$ College of Agriculture, Hanumanamatti, Haveri, UAS, Dharwad, India \\ ${ }^{3}$ College of Forestry, Sirsi, Uttar Kannada, UAS, Dharwad, India \\ *Corresponding author
}

\begin{abstract}
A B S T R A C T
\section{Keywords}

Soft rot, $P$. aphanidermatum, Sclerotium rolfsii, $R$. solanacearum and Fusarium solani

Article Info

Accepted:

12 November 2020

Available Online:

10 December 2020

India is renowned throughout the world as "spice bowl" due to production and export of spices. Ginger is an economically important cash crop grown for its aromatic underground rhizomes. Rhizome rot or soft rot is the most destructive diseases of ginger worldwide. The pathogen associated with rhizome rot complex disease of ginger in Karnataka includes Pythium aphanidermatum (causes soft rot), Ralstonia solanacearum (bacterial wilt), Fusarium solani (yellows), Sclerotium rolfsii (Sclerotium rot) and Meloidogyne arenaria (root knot). In the interaction study, $R$. solanacearum took 16 days to express the symptoms in individual inoculation with highest rot incidence $(55.56 \%)$. In case of $P$. aphanidermatum, the symptoms were expressed within 19 days after inoculation with 43.55 per cent disease incidence. The symptoms were seen within $10 \mathrm{DAI}$ with all pathogens $(\mathrm{P}+\mathrm{F}+\mathrm{R}+\mathrm{S}+\mathrm{M})$. In sequential inoculation of $M$. arenaria followed by $R$. solanacearum after 15 days, recorded maximum incidence of disease $(91.67 \%)$. The disease was expressed in 21 DAI of pathogens.
\end{abstract}

\section{Introduction}

India is renowned throughout the world as "spice bowl" due to production and export of spices. The spices contribute 1.24 per cent to total export and 8.50 per cent to agriculture export (Karthick et al., 2015). The major spices crops include black pepper, chilli, cardamom, coriander, ginger, turmeric etc. Among them ginger is important one. Ginger is botanically known as Zingiber officinale, belongs to family Zingiberaceae. It's an economically important cash crop grown for its aromatic underground rhizomes, which is used as a both spice and medicine purpose. Spicy aroma in ginger is due to the presence of principle component ketones (Bode and Dong, 2011). Refreshing pleasant aroma, carminative and biting taste of ginger made it indispensable ingredient in food preparation throughout the world.

Currently our country is the largest producer of ginger globally with 168 thousand hectares 
under its cultivation with production potential of 10.70 lakh tones. The average productivity of ginger in India is around 6.5 tonnes/ha. Karnataka stands $4^{\text {th }}$ in area and production of ginger and the growing districts are viz., Uttara Kannada, Shivamogga, Haveri, Bidar, Hassan, Kodagu and Mysuru. Around 29.3 thousand ha. is under ginger with annual production of 109.3 thousand tonnes. This has wide usage in ayurvedic possessing antifungal, anti-bacterial, anti-tumorigenic, antiinflammatory, anti-apoptotic, antihyperglycemic, anti-oxidant, anti-emetic and immune-modulatory property that too without any side effects (Badredin et al., 2008). Ginger is a highly succulent herb and its rhizomes are highly susceptible to different abiotic and biotic stresses. Among them major constraint in ginger production is rhizome rot complex disease. Rhizome rot or soft rot is the most destructive diseases of ginger worldwide caused by the association of fungi, bacterium and plant parasitic nematode (Dohroo, 2005).The pathogen associated with rhizome rot complex disease of ginger in
Karnataka includes Pythium aphanidermatum (causes soft rot), Ralstonia solanacearum (E. F. Smith) Yabuuchi et al., 1995 (bacterial wilt), Fusarium solani (yellows), Sclerotium rolfsii (Sclerotium rot) and Meloidogyne arenaria (root knot) as reported by Anand (2014). The rhizome rot disease is complex in nature and also organisms associated with the disease vary with different growth stages of crop and different geographical area. Hence there is a need to study the association between different pathogens associated with rhizome rot complex disease of ginger.

\section{Materials and Methods}

Green house experiment was conducted to study the interaction among the different rhizome rot pathogens of ginger viz., $P$. aphanidermatum, F. solani, $S$. rolfsii, $R$. solanacearum and $M$. arenaria. For each treatment three replications were maintained. The experimental details are presented here under.

\begin{tabular}{|c|c|}
\hline Sl. No & Treatments \\
\hline $\mathbf{1}$ & Pythium aphanidermatum alone $(\mathrm{P})(6 \%$ Inoculum $)$ \\
\hline $\mathbf{2}$ & Fusarium solani alone $(\mathrm{F})(6 \%$ Inoculum) \\
\hline $\mathbf{3}$ & Ralstonia solanacearum alone $\left(1 \mathrm{X} 10^{-7} \mathrm{cfu} / \mathrm{ml}\right)$ \\
\hline $\mathbf{4}$ & Sclerotium rolfsii $(\mathrm{S})(4 \%$ Inoculum $)$ \\
\hline $\mathbf{5}$ & Meloidogyne arenaria alone $(\mathrm{M})(2 \mathrm{juveniles} \mathrm{per} \mathrm{gram} \mathrm{of} \mathrm{soil)}$ \\
\hline $\mathbf{6}$ & $\mathrm{P}+\mathrm{F}$ (Simultaneous inoculation) \\
\hline $\mathbf{7}$ & $\mathrm{P}+\mathrm{R}$ (Simultaneous inoculation) \\
\hline $\mathbf{8}$ & $\mathrm{P}+\mathrm{S}$ (Simultaneous inoculation) \\
\hline $\mathbf{9}$ & $\mathrm{P}+\mathrm{M}$ (Simultaneous inoculation) \\
\hline $\mathbf{1 0}$ & $\mathrm{P}+\mathrm{F}+\mathrm{M}$ (Simultaneous inoculation) \\
\hline $\mathbf{1 1}$ & $\mathrm{P}+\mathrm{R}+\mathrm{M}$ (Simultaneous inoculation) \\
\hline $\mathbf{1 2}$ & $\mathrm{P}+\mathrm{S}+\mathrm{M}$ (Simultaneous inoculation) \\
\hline $\mathbf{1 3}$ & $\mathrm{P}+\mathrm{F}+\mathrm{R}+\mathrm{M}$ (Simultaneous inoculation) \\
\hline $\mathbf{1 4}$ & $\mathrm{P}+\mathrm{F}+\mathrm{R}+\mathrm{S}+\mathrm{M}$ (Simultaneous inoculation) \\
\hline $\mathbf{1 5}$ & $\mathrm{P}$ followed by F inoculation after 15 days \\
\hline $\mathbf{1 6}$ & $\mathrm{P}$ followed by R inoculation after 15 days \\
\hline $\mathbf{1 7}$ & $\mathrm{P}$ followed by S inoculation after 15 days \\
\hline $\mathbf{1 8}$ & $\mathrm{P}$ followed by M inoculation after 15 days \\
\hline
\end{tabular}




\begin{tabular}{|r|l|}
\hline $\mathbf{1 9}$ & F followed by P inoculation after 15 days \\
\hline $\mathbf{2 0}$ & F followed by R inoculation after 15 days \\
\hline $\mathbf{2 1}$ & F followed by S inoculation after 15 days \\
\hline $\mathbf{2 2}$ & F followed by M inoculation after 15 days \\
\hline $\mathbf{2 3}$ & M followed by P inoculation after 15 days \\
\hline $\mathbf{2 4}$ & M followed by F inoculation after 15 days \\
\hline $\mathbf{2 5}$ & M followed by R inoculation after 15 days \\
\hline $\mathbf{2 6}$ & M followed by S inoculation after 15 days \\
\hline $\mathbf{2 7}$ & P followed by M inoculation after 15 days \\
\hline $\mathbf{2 8}$ & F followed by M inoculation after 15 days \\
\hline $\mathbf{2 9}$ & R followed by M inoculation after 15 days \\
\hline $\mathbf{3 0}$ & S followed by M inoculation after 15 days \\
\hline $\mathbf{3 1}$ & Uninoculated control \\
\hline
\end{tabular}

Fungal pathogens were multiplied in corn sand agar and inoculum was added to pot containing 40 days old plants of susceptible variety of ginger ( $\mathrm{Cv}$. Reo-de-janeiro) was planted in pot and the soil moisture was maintained to field capacity level. Observations on germination, disease incidence and death of plants were recorded periodically. Finally reisolation of pathogens was made to confirm the association.

\section{Results and Discussion}

Interaction study of different pathogens were carried out in glass house condition Pathogens were inoculated individually and in combination by using giant culture as mentioned in section. Observations such as per cent rot incidence, number of days taken to appear symptoms and pathogen detected were recorded (Table 1).

All inoculated plants induced rhizome rot disease symptoms except in uninoculated control. When individual pathogens were inoculated, plants produced varying symptoms in different days. When $R$. solanacearum alone was inoculated, plants induced within 16 days after inoculation. The inoculated plant produced symptoms such as bronzing of lower leaves followed by inward rolling, which proceeds upwards. Later plant showed wilting symptoms and finally rotting of rhizomes with foul smell. $R$. solanacearum alone inoculated plants were recorded 55.56 per cent disease incidence.

In case of $P$. aphanidermatum, the symptoms were expressed within 19 days after inoculation with the symptoms likes foliar yellowing, pseudostem as well as rhizome rotting with foul smell. In case of soft rot 43.55 per cent disease incidence was recorded. In case of single inoculation of $F$. solani exhibited symptoms 40 days after inoculation with 33.33 per cent rot incidence. When plants were inoculated with $S$. rolfsii alone, the symptoms was observed 28 days after inoculation with rot incidence of 31.67 per cent. The plants inoculated with $M$. arenaria exhibited symptoms 55 days after inoculation with incidence of 16.67 per cent.

The pathogens took 10-21 days to express symptoms during combined inoculation of rhizome rot pathogens. The incidence of disease ranges from 45.00 to 73.33 per cent. When the plants were simultaneous inoculation with the all pathogens $(\mathrm{P}+\mathrm{F}+\mathrm{R}$ $+\mathrm{S}+\mathrm{M})$, the symptoms were seen within 10 DAI with rhizome rot incidence of 73.33 per cent. In case of $\mathrm{P}+\mathrm{F}+\mathrm{R}+\mathrm{M}$ combination 
recorded 70.00 per cent rot incidence, this was statistically on par with the combined inoculation of $\mathrm{P}+\mathrm{R}+\mathrm{M}(72.22 \%)$ and $\mathrm{P}+\mathrm{F}$ $+\mathrm{R}+\mathrm{S}+\mathrm{M}(73.33 \%)$. When the pathogens were reisolated from the rotted rhizome, it was found that most of the combination $S$. rolfsii and Meloidogyne were not recovered. The incidence of rhizome rot disease was more in combined inoculation of pathogens as compared to individual inoculation except in $\mathrm{P}+\mathrm{S}(49.44 \%)$ and $\mathrm{P}+\mathrm{M}(45.00 \%)$.
In case of sequential inoculation of pathogens, when the nematode was inoculated first and followed by other pathogen recorded highest per cent rhizome rot incidence as compared to other treatments. In sequential inoculation of $M$. arenaria followed by $R$. solanacearum after 15 days was recorded maximum incidence of disease $(91.67 \%)$. The disease was expressed within 21 DAI of pathogens. The results indicated that, $F$. solani and $S$. rolfsii were weak pathogens as compared to other pathogens of rhizome rot of ginger.

Table.1 Interaction of different pathogens associated with rhizome rot complex disease in ginger

\begin{tabular}{|c|c|c|c|c|}
\hline Sl. No. & Treatments & $\begin{array}{l}\text { Rot incidence } \\
\text { (PDI) }\end{array}$ & $\begin{array}{l}\text { Appearance of } \\
\text { symptoms } \\
\text { (DAI)** }\end{array}$ & Pathogen reisolated \\
\hline 1 & Pythium aphanidermatum alone (P) & $\begin{array}{c}44.44 \\
(41.75)^{*}\end{array}$ & 19 & P. aphanidermatum \\
\hline 2 & Fusarium solani alone (F) & $\begin{array}{c}33.33 \\
(34.79)\end{array}$ & 40 & F. solani \\
\hline 3 & Ralstonia solanacearum alone & $\begin{array}{c}55.56 \\
(48.23)\end{array}$ & 16 & R. solanacearum \\
\hline 4 & Sclerotium rolfsii $(\mathrm{S})$ & $\begin{array}{c}31.67 \\
(33.86)\end{array}$ & 28 & S. rolfsii \\
\hline 5 & Meloidogyne arenaria alone (M) & $\begin{array}{l}16.67 \\
(24.09)\end{array}$ & 55 & M. arenaria \\
\hline 6 & $\mathrm{P}+\mathrm{F}$ (Simultaneous inoculation) & $\begin{array}{c}54.60 \\
(47.69)\end{array}$ & 20 & $\begin{array}{l}\text { P. aphanidermatum }+F \text {. } \\
\text { solani }\end{array}$ \\
\hline 7 & $\mathrm{P}+\mathrm{R}$ (Simultaneous inoculation) & $\begin{array}{c}74.67 \\
(59.79)\end{array}$ & 12 & $\begin{array}{l}P . \text { aphanidermatum }+R \text {. } \\
\text { solanacearum }\end{array}$ \\
\hline 8 & $\mathrm{P}+\mathrm{S}$ (Simultaneous inoculation) & $\begin{array}{c}49.44 \\
(44.83)\end{array}$ & 21 & $\begin{array}{l}\text { P. aphanidermatum }+S \text {. } \\
\text { rolfsii }\end{array}$ \\
\hline 9 & $\mathrm{P}+\mathrm{M}$ (Simultaneous inoculation) & $\begin{array}{c}45.00 \\
(41.92)\end{array}$ & 20 & P. aphanidermatum \\
\hline 10 & $\mathrm{P}+\mathrm{F}+\mathrm{M}$ (Simultaneous inoculation) & $\begin{array}{c}53.33 \\
(46.92)\end{array}$ & 18 & $\begin{array}{l}\text { P. aphanidermatum }+F \text {. } \\
\text { solani }\end{array}$ \\
\hline 11 & $\mathrm{P}+\mathrm{R}+\mathrm{M}$ (Simultaneous inoculation) & $\begin{array}{c}72.22 \\
(58.25)\end{array}$ & 12 & $\begin{array}{l}P . \text { aphanidermatum }+R . \\
\text { solanacearum }\end{array}$ \\
\hline 12 & $\mathrm{P}+\mathrm{S}+\mathrm{M}$ (Simultaneous inoculation) & $\begin{array}{c}57.38 \\
(49.45)\end{array}$ & 18 & $\begin{array}{l}P . \text { aphanidermatum }+S . \\
\text { rolfsii }\end{array}$ \\
\hline 13 & $\mathrm{P}+\mathrm{F}+\mathrm{R}+\mathrm{M}$ (Simultaneous inoculation) & $\begin{array}{c}70.00 \\
(61.92)\end{array}$ & 10 & $\begin{array}{l}P . \text { aphanidermatum }+F . \\
\text { solani }+R . \text { solanacearum }\end{array}$ \\
\hline 14 & $\mathrm{P}+\mathrm{F}+\mathrm{R}+\mathrm{S}+\mathrm{M}$ (Simultaneous inoculation) & $\begin{array}{c}73.33 \\
(63.85)\end{array}$ & 10 & $\begin{array}{l}P . \text { aphanidermatum }+F . \\
\text { solani }+R . \text { solanacearum }\end{array}$ \\
\hline 15 & $\mathrm{P}$ followed by $\mathrm{F}$ inoculation after 15 days & $\begin{array}{c}47.22 \\
(43.51)\end{array}$ & 24 & P. aphanidermatum \\
\hline 16 & $\mathrm{P}$ followed by $\mathrm{R}$ inoculation after 15 days & $\begin{array}{c}58.89 \\
(50.10)\end{array}$ & 18 & $\begin{array}{l}P . \text { aphanidermatum }+R \text {. } \\
\text { solanacearum }\end{array}$ \\
\hline 17 & $\mathrm{P}$ followed by $\mathrm{S}$ inoculation after 15 days & 50.00 & 20 & P. aphanidermatum \\
\hline
\end{tabular}




\begin{tabular}{|c|c|c|c|c|}
\hline & & $(44.98)$ & & \\
\hline 18 & $\mathrm{P}$ followed by $\mathrm{M}$ inoculation after 15 days & $\begin{array}{c}44.44 \\
(41.78)\end{array}$ & 22 & P. aphanidermatum \\
\hline 19 & $\mathrm{~F}$ followed by $\mathrm{P}$ inoculation after 15 days & $\begin{array}{c}52.78 \\
(46.58)\end{array}$ & 32 & $\begin{array}{l}\text { P. aphanidermatum }+F \text {. } \\
\text { solani }\end{array}$ \\
\hline 20 & $\mathrm{~F}$ followed by $\mathrm{R}$ inoculation after 15 days & $\begin{array}{c}62.22 \\
(52.07)\end{array}$ & 24 & $\begin{array}{l}F . \text { solani }+R . \\
\text { solanacearum }\end{array}$ \\
\hline 21 & $\mathrm{~F}$ followed by $\mathrm{S}$ inoculation after 15 days & $\begin{array}{c}52.22 \\
(46.27)\end{array}$ & 35 & F. solani + S. rolfsii \\
\hline 22 & $\mathrm{~F}$ followed by $\mathrm{M}$ inoculation after 15 days & $\begin{array}{c}38.89 \\
(38.56)\end{array}$ & 35 & F. solani \\
\hline 23 & M followed by $\mathrm{P}$ inoculation after 15 days & $\begin{array}{c}75.00 \\
(60.21)\end{array}$ & 26 & P. aphanidermatum \\
\hline 24 & $\mathrm{M}$ followed by $\mathrm{F}$ inoculation after 15 days & $\begin{array}{c}67.22 \\
(55.17)\end{array}$ & 35 & M. arenaria $+F$. solani \\
\hline 25 & $\mathrm{M}$ followed by $\mathrm{R}$ inoculation after 15 days & $\begin{array}{l}91.67 \\
(80.00)\end{array}$ & 21 & R. solanacearum \\
\hline 26 & M followed by $\mathrm{S}$ inoculation after 15 days & $\begin{array}{c}44.44 \\
(41.75)\end{array}$ & 30 & M. arenaria $+S$. rolfsii \\
\hline 27 & $\mathrm{P}$ followed by $\mathrm{M}$ inoculation after 15 days & $\begin{array}{c}55.00 \\
(47.86)\end{array}$ & 20 & P. aphanidermatum \\
\hline 28 & F followed by $\mathrm{M}$ inoculation after 15 days & $\begin{array}{c}38.89 \\
(38.53)\end{array}$ & 35 & M. arenaria $+F$. solani \\
\hline 29 & $\mathrm{R}$ followed by $\mathrm{M}$ inoculation after 15 days & $\begin{array}{c}69.44 \\
(56.47)\end{array}$ & 16 & R. solanacearum \\
\hline 30 & S followed by $\mathrm{M}$ inoculation after 15 days & $\begin{array}{c}33.33 \\
(35.25)\end{array}$ & 30 & M. arenaria $+S$. rolfsii \\
\hline 31 & Uninoculated control & $\begin{array}{c}00.00 \\
(00.00)\end{array}$ & & \\
\hline & S. Em. \pm & 1.39 & & \\
\hline & C.D. @1\% & 5.42 & & \\
\hline
\end{tabular}

These interaction studies results were similar with the findings of Shalini (2006) reported that the $P$. aphanidermatum and $F$. solani complex in ginger and turmeric rhizome rot disease. F. solani and S. rolfsii were weak pathogens as compared to other pathogens of rhizome rot of ginger. Association of Pythium spp. especially $F$. solani and $F$. equiseti has been demonstrated (Bhardwaj et al., 1988) and interaction of Ceratocystis fimbriata and Meloidogyne incognita in Pomegranate was reported by Sonyal et al., (2016). In artificial inoculation tests it has been demonstrated that maximum rotting occurred only when $P$. aphanidermatum was inoculated first followed by $F$. solani (Doshi and Mathur, 1987). The individual and interactive effects of $M$. incognita with $P$. aphanidermatum and
$R$. solanacearum in ginger were demonstrated by Ramana et al., (1998).

When the plants were simultaneous inoculation with the all pathogens $(\mathrm{P}+\mathrm{F}+\mathrm{R}$ $+\mathrm{S}+\mathrm{M})$, the symptoms were seen within 10 DAI with rhizome rot incidence of 73.33 per cent. The incidence of rhizome rot disease was more in combined inoculation of pathogens as compared to individual inoculation. This result were similar with the observation of Chauhan and Patel, 1990, independent infection and interaction between Pythium spp. and $F$. solani leading to synergy. Vadhera et al., (1992) reported synergy of $P$. aphanidermatum and $M$. javanica in ginger from Madhya Pradesh. Gogoi et al., (2008) identify the association of 
$R$. solanacearum $+F$. oxysporum f. $\mathrm{sp}$. zingiberi and $R$. solanacearum $+P$. myriotylum.

In sequential inoculation of $M$. arenaria followed by $R$. solanacearum after 15 days was recorded maximum incidence of disease $(91.67 \%)$. The disease was expressed within 21 DAI of pathogens. Similar trend was observed by Ateka et al., (2001) reported the interaction nature of $R$. solanacearum and $M$. incognita. The presence of $M$. incognita increases the severity of the disease in potato (Siddiqui et al., 2014), Tomato (Sundaresh et al., 2017).

In the interaction study, $R$. solanacearum took 16 days to express the symptoms in individual inoculation with highest rot incidence (55.56 $\%)$. In case of $P$. aphanidermatum, the symptoms were expressed within 19 days after inoculation with 43.55 per cent disease incidence. The symptoms were seen within 10 DAI with all pathogens $(\mathrm{P}+\mathrm{F}+\mathrm{R}+\mathrm{S}+\mathrm{M})$. In sequential inoculation of $M$. arenaria followed by $R$. solanacearum after 15 days, recorded maximum incidence of disease $(91.67 \%)$. The disease was expressed in 21 DAI of pathogens.

\section{References}

Anand, I. D., 2014, Investigations on bacterial wilt of ginger caused by Ralstonia solanacearum (E. F. Smith) Yabucchi et al.. M. Sc. Thesis. Univ. Agric Sci. Dharwad, Karnataka (India).

Ateka, E. M., Mwangombe, A. W and Kimenju, J. W., 2001, Studies on the interaction between Ralstonia solanacearum (smith) and Meloidogyne spp. in potato. African Crop Sci. J., 9 (3): 527-535.

Badreldin, H. A., Gerald, B., Musbah, O. T., Abderrahim, N., 2008, Some phytochemical, pharmacol and toxicological properties of ginger (Zingiber officinale Roscoe): A review of recent research: Food Chem. Toxicol., 46(2): 409-420.

Bhardwaj, S. S., Gupta, P. K., Dohroo, N. P. and Shyam, K. R., 1988, Biological control of rhizome rot of ginger in storage. Indian J. Plant Pathol., 6(1): 56-59.

Bode, A. M. and Dong, Z., 2011, Herbal medicine: biomolecular and clinical Aspects. $2^{\text {nd }}$ edition. CRC Press/Taylor \& Francis, England and Wales (Books)

Chauhan, H. L. and Patel, M. H., 1990, Etiology of complex rhizome rot of ginger (Zingber officinale) in Gujarat and in vitro screening of fungicides against causal agents. Indian J. Agric. Sci., 60: 80-81.

Dohroo, N. P., 2005. Diseases of ginger. In: The genus Zingiber. Rabindran, P.N. and Nirmal Babu, K (Eds), CRC, Press, Boca Raton, Florida, USA. pp304-340.

Doshi, A. and Mathur, S., 1987, Symptomatology, interaction and management of rhizome rot of ginger by xenobiotics. Korean J. Appl. Entomol., 26 (4): 261-265.

Gogoi, D. K., Deka Boruah, H. P., Saikia, R. and Tarun, C. B., 2008, Optimization of process parameters for improved production of bioactive metabolite by a novel endophytic fungus Fusarium sp. DF2 isolated from Taxus wallichiana of North East India. World J. Microbiol. Biotechnol., 24: 79-87.

Karthick, V., Alagumani, T. and Anbarassan, A., 2015, Growth and export performance of ginger in India-An economic analysis. Economic affairs. 60 (2): 207-14.

Ramana, K. V. and Eapen, S. J. 1995. Parasitic nematodes and their management in major spices. JOSAC., 4 (1): 1-16.

Shalini, D. S., 2006, Investigations on the 
etiology, epidemiology and integrated management of rhizome rot complex of ginger and turmeric. Ph. D. Thesis. Univ. Agric Sci. Dharwad (India).

Siddiqui, Z. A., Mohd, S. and Alam, S., 2014, Interactions of Ralstonia solanacearum and Pectobacterium carotovorum with Meloidogyne incognita on potato. Arch. Phytopathol. Pl Protec., 47 (4): 449455.

Sonyal, S., Nargund, V. B., Yallappa, J., Benagi, V. I., Palanna, K. B., Giri, M. S., Pappachan, A., Shivalingappa, H., Mahesha, H. S., Dev, D. and Puneeth, M. E., 2016, Management of pomegranate wilt complex caused by
Ceratocystis fimbriata and Meloidogyne incognita. J. Pure Appl. Microbio., 10(1):157-161.

Sundaresh, Devappa, V., Archith, T. C. and Nagnur, P., 2017, Interaction of Ralstonia solanacearum and Meloidogyne incognita on Tomato (Solanum lycopersicon L.). Int. J. Curr. Microbiol. App. Sci., 6 (9): 156-160. Vadhera, I., Tiwari, S. P. and Shukla, B. N., 1992, Inter-relationship between Pythium aphanidermatum causing soft rot and Meloidogyne javanica causing root knot of ginger. Indian J. Mycol. Plant Pathol., 22: 236-239.

\section{How to cite this article:}

Mahesha, H. S., M. R. Ravikumar, V. Suryanarayana, S. T. Prabhu and Jagadeesh, B. R. 2020. Interaction of Pathogens Associated with Rhizome Rot Complex Disease in Ginger. Int.J.Curr.Microbiol.App.Sci. 9(12): 1460-1466. doi: https://doi.org/10.20546/ijcmas.2020.912.173 